\title{
Characterization, classification and analysis of the main properties of the Southwestern Goias soil
}

\author{
Caracterização, classificação e análise das principais propriedades \\ dos solos do Sudoeste Goiano
}

\author{
Kathleen Lourenço Fernandes ${ }^{1 *}$; Adriana Aparecida Ribon²; José Marques Junior ${ }^{3}$; \\ Angélica Santos Rabelo de Souza Bahia ${ }^{4}$; João Tavares Filho
}

\begin{abstract}
Characterization of the soil and the grouping of its properties through main component analysis can assist in the classification and observation of the consequences of the conversion of native forest areas in pastures. Such data can aid in management practices. Considering the lack of studies in Cerrado soils of south-western Goias, developed metagranites of Jurubatuba suite, the objective was to classify and study the physical, chemical and mineralogical soil (under native forest and pasture) Southwest of Goias. Soil sampling and classification followed the Field Methods Manual and the Brazilian System of Soil Classification, respectively. The physical, chemical and mineralogical soil were studied, as well as main component analysis made for these attributes. The profile 1 under native forest was classified as "Cambissolo Háplico Tb eutrófico latossólico". The profile 2 under degraded pasture was rated "Latossolo Amarelo eutrófico típico". In addition, the profile 3 under rotated pasture was rated as "Latossolo Vermelho eutrófico chernossólico". It was observed that the "Latossolos" have higher bulk density and soil penetration resistance, indicating greater soil compaction. They showed high amounts of iron oxides and minor amount of nutrients such as calcium and magnesium. The principal component analysis allowed the grouping of profiles into two groups. Group 1 brought together the properties related to "Latossolos", and the second was related to "Cambissolo" properties. Thus, the principal components analysis aids the understanding of soil properties and the grouping of soils with similar characteristics, the level of order and management.
\end{abstract}

Key words: Cambissolo. Latossolos. Iron and aluminum oxides.

\section{Resumo}

A caracterização do solo e o agrupamento de suas propriedades por meio de análise de componentes principais podem auxiliar na classificação e na observação das consequências da conversão de áreas de mata nativa em pastagens. Tais dados podem auxiliar nas práticas de manejo adotadas. Considerando a ausência de estudos em solos do Cerrado do sudoeste goiano, desenvolvidos de metagranitos da suíte Jurubatuba, o objetivo deste trabalho foi classificar e estudar as propriedades físicas, químicas e mineralógicas de solos (sob mata nativa e pastagens) do Sudeste Goiano. As coletas de solo e

1 Discente do Curso de Mestrado do Programa de Pós-Graduação em Agronomia/Ciência do Solo, Universidade Estadual Paulista "Júlio de Mesquita Filho", UNESP, Jaboticabal, SP, Brasil. E-mail: kathleen_agro@hotmail.com

2 Prof ${ }^{a}$ Dra , Universidade Estadual de Goiás, UEG, Palmeiras de Goiás, GO, Brasil. E-mail: aaribon@yahoo.com.br

3 Prof. Dr., Programa de Pós-Graduação Ciência do Solo e Produção Vegetal, UNESP, Jaboticabal, SP, Brasil. E-mail: marques@ fcav.unesp.br

4 Discente do Curso de Doutorado do Programa de Pós-Graduação em Agronomia/Ciência do Solo, UNESP, Jaboticabal, SP, Brasil. E-mail: angelicasantosrabelo@yahoo.com.br

5 Prof. Dr., Departamento de Agronomia, Centro de Ciências Agrárias, Universidade Estadual de Londrina, UEL, Londrina, PR, Brasil. E-mail: tavares@uel.br

* Author for correspondence 
classificação seguiram o Manual de Métodos de Campo e o Sistema Brasileiro de Classificação de Solos, respectivamente. Foram estudadas as propriedades físicas, químicas e mineralógicas dos solos, bem como feitas análises de componentes principais desses atributos. O perfil 1 sob mata nativa foi classificado como Cambissolo Háplico Tb eutrófico latossólico. O perfil 2 sob pastagem extensiva foi classificado como Latossolo Amarelo eutrófico típico. E o perfil 3 sob pastagem rotacionada foi classificado como Latossolo Vermelho eutrófico chernossólico. Observou-se que os Latossolos apresentaram maiores valores de densidade do solo e resistência do solo à penetração, indicando maior compactação dos solos. Os mesmos apresentaram maiores quantidades de óxidos de ferro e menor quantidade de nutrientes, como cálcio e magnésio. A análise de componentes principais permitiu o agrupamento dos perfis em dois grupos. O Grupo 1 reuniu as propriedades relacionadas aos Latossolos, e o segundo foi relacionado às propriedades do Cambissolo. Assim, a análise dos componentes principais auxilia a compreensão das propriedades dos solos e no agrupamento de solos com características semelhantes, a nível de ordem e de manejo.

Palavras-chave: Cambissolo. Latossolo. Óxidos de ferro e alumínio.

\section{Introduction}

The Cerrado biome covers vast expanse of Brazil, and like different areas of the country, has territories at different stages of degradation. In a very general way, it is considered that nearly every biome is formed by deep Oxisol (Latossolos) low in nutrients and high acidity. However, the homogeneity or heterogeneity is proportional to work scale, a work that is rarely held by farmers.

The attempt to reduce soil degradation rates and increase the productivity of various cultures of the region requires detailed knowledge on local soils and its main features. The soil, in particular, should be considered a non-renewable resource, which determines life to a diversity of plants and microorganisms (REATTO et al., 2008), so if not maintained and managed properly can have many implications both environmental, as economic and social.

In this aspect, the classification and characterization of soil help in forming a base of information supporting the use of techniques for sustainable use and management of soils, preventing the degradation process. Souza et al. (2010), explain that the characterization for soil conservation purposes and the environment that surrounds it, makes the study of physical, chemical, morphological and mineralogical soil, means that aid in the understanding of their genesis, their ability and their limitations.
In field works the correlation of related attributes to forest profiles or pasture areas is made empirically, based on the experience of each professional, and there may be divergence between thoughts. Therefore, the multivariate analysis, by the main component analysis allows better understanding and interpretation of these relations, for easy change attribute (organic matter, soil bulk density, soil resistance to penetration) or not (sand, silt, clay, minerals, etc.).

Brossard and Barcellos (2005) point out that the conversion of Latosols under Cerrado pastures decreases in the level of organic matter (OM), the concentration of phosphate ions and the amount of total pores, contributing to the formation of a compacted layer. Resende et al. (2012) observed that the conversion of native Cerrado to pasture has changed the structure of the studied "Latossolo", by decreasing the macro porosity and total porosity, increased soil density and alteration of soil aggregation. As a result, one can observe a decrease in pasture productivity and productive capacity of the soil.

Noting the lack of studies in the Southwest Goias Cerrado soils, developed metagranites of Jurubatuba suite, this study aims to classify and study the physical, chemical and mineralogical soil under native forest and pasture in order to assist in the understanding of active pedogenic processes. 


\section{Material and Methods}

The study area is located in the municipality of Campestre in the state of Goias, at coordinates 16 ○ 46'39 ' S latitude and 49 ${ }^{\circ} 44^{\prime} 38^{\prime \prime}$ 'W longitude, located in the Cerrado biome. The climate, according to Köppen classification is rainy tropical type (Aw), with dry winters and rainy summers, with rainfalls concentrated in the months from October to March, and the average temperature of the coldest month is greater than $18^{\circ} \mathrm{C}$ (RIBEIRO; WALTER, 2008).
The source material of the area consists of metagranites of metamorphic origin of Jurubatuba formation (Figure 1) of Proterozoic age, located in the central Brazilian plateau with gentle to corrugated terrain (IBGE, 2004). The primary vegetation is represented by savanna vegetation type of formation, Cerrado in the strict sense (IBGE, 2004; RIBEIRO, WALTER, 2008).

Figure 1. Geology of the study area and location of the profiles studied. Profile 1 (P1); profile 2 (P2) and profile 3 (P3).

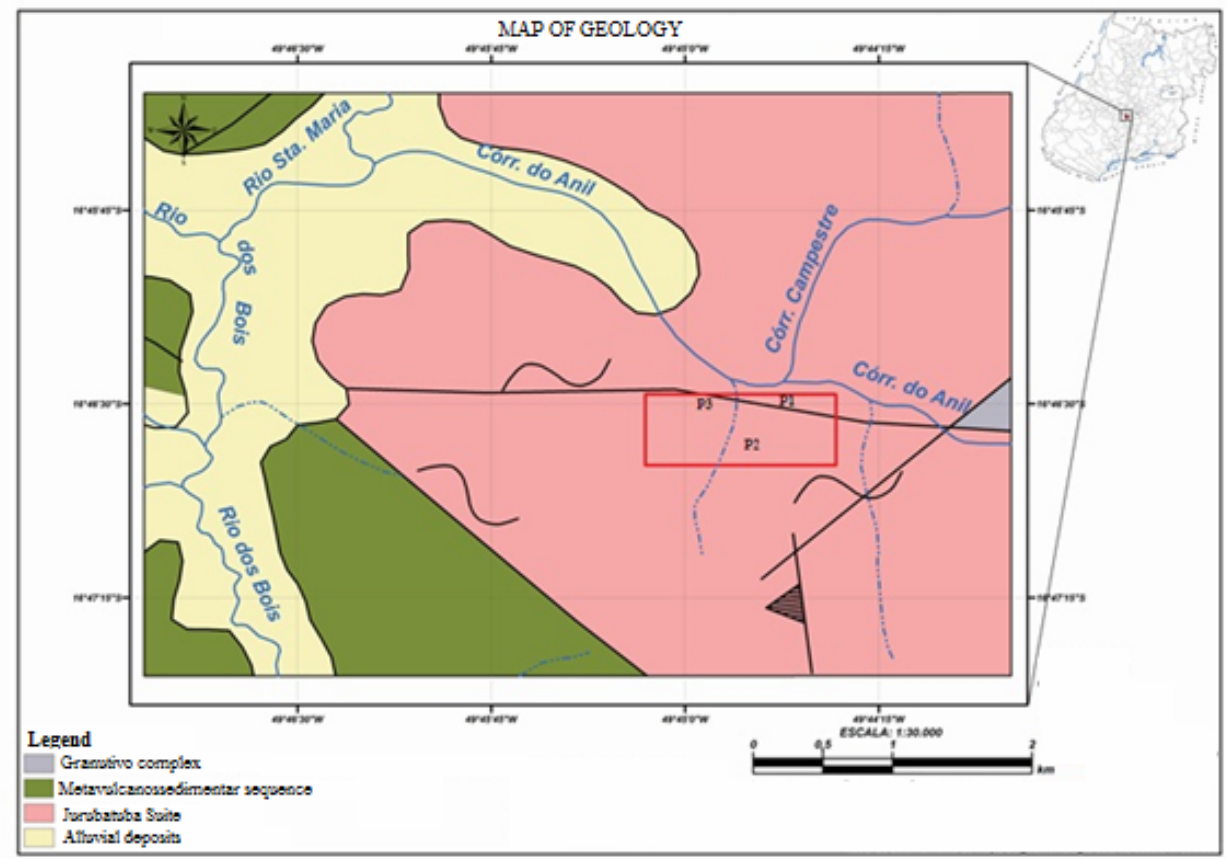

Three soil profiles were selected for the study, as the property size and layout of the different management systems. The profiles were about 100 meters apart. Profile 1 - was under native forest, located in the lower portion and more corrugated area (585 $\mathrm{m}$ altitude); Profile 2 - under degraded pasture with Brachiaria grass, established 6 years ago, located in the flat portion of the area $(603 \mathrm{~m}$ altitude); and Profile 3 - under rotated pasture, guinea-grass with rotation of animals every $24 \mathrm{~h}$, also located on the flatter portion of the area $(603 \mathrm{~m}$ altitude) (Figure 1).
The profile s were described in the trench and the morphological characterization and sampling of horizons was performed following Santos et al. (2013). Deformed samples were collected from each horizon for performing physical, chemical, mineralogical, and undisturbed samples in the first soil horizons (arable layer) for bulk density analysis (BD). In the field it was also determined the soil resistance to penetration (PR) in the arable layer (first $0.40 \mathrm{~m}$ of the profile). The classification of the profiles was conducted using the methodology of Embrapa (2013) until the sixth category level in 
order to characterize them as the morphological, physical, chemical and mineralogical.

The color of damp soil was carried out in the field, and the color of the dry soil in the laboratory using a color chart of Munsell soil. The physical, chemical and mineralogical analyzes were determined on dry material in the air, bluffing and passing through a sieve of $2 \mathrm{~mm}$ aperture for obtaining fine air dry land (FADL), following the methodology of the EMBRAPA (2011). The clay was determined by the pipette method. The $\mathrm{pH}$ was determined in $\mathrm{H}_{2} \mathrm{O}$ and $\mathrm{CaCl}_{2}$. The organic carbon (C) was obtained by the volumetric method by oxidation. The divalent exchangeable cations $\left(\mathrm{Ca}^{+2}\right.$ and $\mathrm{Mg}^{+2}$ ) and exchangeable acidity $\left(\mathrm{Al}^{+3}\right)$ were extracted with $\mathrm{KCl}_{1} \mathrm{~mol} \mathrm{~L}^{-1}$ and determined by titration. The exchangeable potassium was analyzed by the photometric method directly in soil with Mehlich obtained extract solution 1. The potential acidity was determined by volumetric method with calcium acetate extraction by $0.5 \mathrm{~mol}^{-1}$ at $\mathrm{pH}$ 7.0. From these data, we calculated: silt / clay ratio, sum of bases (SB), exchangeable hydrogen, cation exchange capacity (CEC), clay fraction activity (CFA), base saturation (BS) and percentage of Al saturation (Al. sat.), cation retention (CR) and organic matter (OM) (EMBRAPA, 2011).

Bulk density analyzes, particle density, total porosity and available water capacity (AWC) followed the methodology of Embrapa (2011). The AWC was obtained by obtaining the tensions in Richards's chamber with porous plate and soil density analyzed by the sharp edges ring method, using a ring with $63 \mathrm{~cm}^{3}$. The particle density was determined by volumetric flask method and total porosity was obtained in the Richards chamber. The soil penetration resistance was evaluated according to the methodology Stolf (1991) using an impact penetrometer Model IAA/Planalsucar.

The total iron $\left(\mathrm{Fe}_{2} \mathrm{O}_{3}\right)$ was determined by sulfuric acid attack $\left(\mathrm{H}_{2} \mathrm{SO}_{4}\right)$ for $\mathrm{Al}_{2} \mathrm{O}_{3}$ and $\mathrm{Fe}_{2} \mathrm{O}_{3}$, followed by dissolution at alkaline $\mathrm{SiO}_{2}$, according to the method described by EMBRAPA (2011). The determination of the iron content relative to all the Pedogenic iron oxides extracted by dithionitebicarbonate-citrate $\left(\mathrm{Fe}_{\mathrm{d}}\right)$ followed methodology Mehra and Jackson (1960) and determining the iron contents extracted by ammonium oxalate $\left(\mathrm{Fe}_{\mathrm{o}}\right)$ for pedogenic iron oxides to low crystallinity followed the methodology mentioned by Camargo et al. (1986). Through these analyzes it was possible to calculate weathering's index of $\mathrm{Ki}, \mathrm{Kr}$ and $\mathrm{Fe}_{\mathrm{o}} / \mathrm{Fe}_{\mathrm{d}}$ that assists in the interpretation of the degree of crystallinity of oxides and processes Pedogenic.

For analysis of clay mineralogy soil samples were treated with $\mathrm{NaOH} 0.5 \mathrm{~mol} \mathrm{~L}^{-1}$, subjected to mechanical stirring for $10 \mathrm{~min}$, which promotes dispersion of the particles. Then the sand fraction was withdrawn at $0.05 \mathrm{~mm}$ screen, and then the silt fraction by centrifugation. The clay fraction was flocculated with $\mathrm{HCl}$ 1: 1, and centrifuged (JACKSON, 1985). Fraction of clay minerals hematite $(\mathrm{Hm})$, goethite $(\mathrm{Gt})$, kaolinite $(\mathrm{Kt})$ and gibbsite $(\mathrm{Gb})$ were characterized by $\mathrm{X}$-ray diffraction (XRD) in blades made with no guidance materials (powder).

The characterization of $\mathrm{Gt}$ and $\mathrm{Hm}$ was performed after treatment of the clay fraction with $\mathrm{NaOH} 5 \mathrm{~mol} \mathrm{~L}^{-1}$, to the concentration of these oxides (NORRISH; TAYLOR, 1961; KÄMPF; SCHWERTMANN, 1982). To prevent the reading of diffractograms would be hampered by the sodalite, the samples were washed with $\mathrm{HCl}$ solution $0.5 \mathrm{~mol}$ $\mathrm{l}^{-1}$ (100 $\mathrm{ml}$ of solution / $1 \mathrm{~g}$ of clay), stirred for 4 h. To correct deviations in the position (d) of the reflections studied, the samples were added $10 \mathrm{wt} \%$ sodium chloride milled and sieved into mesh 0.10 $\mathrm{mm}$ before being diffracted.

The characterization of Kt and Gb have been made after the clay fraction be subjected to elimination of iron oxides by dithionite-bicarbonate-citrate method (DBC), according to Mehra and Jackson (1960). The x-ray diffractometer used was Rigaku Mini-Flex II, using cathode copper with nickel filter 
and $\mathrm{Ka}$ radiation $(20 \mathrm{~mA}, 30 \mathrm{kV})$. The sweep speed used was $1^{\circ} 2 \theta$ / minute with range $23-49^{\circ} 2 \theta$ for the characterization of $\mathrm{Hm}$ and $\mathrm{Gt}$, and $11-19^{\circ} 2 \theta$ for the characterization of $\mathrm{Kt}$ and $\mathrm{Gb}$.

Were used to evaluate the consequences $\mathrm{Kt}$ (001), Gb (002), Hm (012 and 110), and Gt (110 and 111). The mean crystallite dimension (MDC) of $\mathrm{Kt}$ and $\mathrm{Gb}$ was calculated from the width at half height $(\mathrm{WHH})$ and the position of the reflections of minerals Kt (001) and Gb (002). The MDC Hm and Gt was calculated from the WHH and the position of the reflections of minerals $\mathrm{Hm}$ (012 and 110) and Gt (110 and 111). It used the equation of Scherrer (KLUG; ALEXANDER, 1974) to calculate the MDC. The reason goethite / (hematite + goethite) $[\mathrm{Gt} /(\mathrm{Gt}+\mathrm{Hm})]$ was calculated using the areas of $\mathrm{Hm}$ reflections (012) and Gt (110). For the calculation of $\mathrm{Gt} /$ ratio $(\mathrm{Gt}+\mathrm{Hm})$, the area of the reflection $\mathrm{Gt}$ (110) was multiplied by 0.35 due to the intensity of $35 \%$ of Hm (012) (KÄMPF; SCHWERTMANN 1998). The kaolinite ratio/(kaolinite + gibbsite $)-$
$[\mathrm{Kt} /(\mathrm{Kt}+\mathrm{Gb})]$ was calculated using the $\mathrm{Kt}$ areas of reflections (001) and $\mathrm{Gb}(002)$. The $\mathrm{Fe}_{\mathrm{d}}$ has been transformed into goethite and hematite content (DICK, 1986).

\section{Results and Discussion}

\section{Morphological description and classification}

In the study areas was not found stony, rockiness or apparent erosion. The profile 1 presented following horizons $\mathrm{A}, \mathrm{A} / \mathrm{B}, \mathrm{Bi}_{1}$ and $\mathrm{Bi}_{2}$ (Table 1) and was classified as "Cambissolo Háplico $\mathrm{Tb}$ eutrófico latossólico (CXbe), argiloso, cascalhento, A Chernozêmico caulinítico oxídico, atividade moderadamente baixa, hipoférrico, moderadamente drenado" (Inceptisol). Although some definitions cite these as shallow soils (OLIVEIRA, 2008), "Cambissolo"with latosolic features different from the standards, as noted in this study, with more than $2.00 \mathrm{~m}$ deep and Ferreira et al. (2009) who found "Cambissolos latossolicos" over $1.70 \mathrm{~m}$ deep.

Table 1. Morfology of "Cambissolo Háplico Tb eutrófico latossólico (CXbe)" (Inceptsol), under native forest.

\begin{tabular}{|c|c|}
\hline Horizon & Depth; color moist; texture; structure; consistence; boundary \\
\hline $\mathbf{A}$ & $\begin{array}{l}\text { 0- } 0.25 \mathrm{~m} \text {, dark live brown }(2.5 \mathrm{Y} 3 / 3 \mathrm{u}) \text {, oliva }(2.5 \mathrm{Y} 4 / 3 \mathrm{~s}) \text {; franco clay; sub angular blocks, } \\
\text { medium, moderate; slightly hard, very friable, not plastic, non sticky; clear wavy transition. }\end{array}$ \\
\hline $\mathbf{A} / \mathbf{B}$ & $\begin{array}{l}0.25-0.65 \mathrm{~m} \text {, brown }(2.5 \mathrm{Y} 3 / 1 \mathrm{u}) \text {, gray to yellow }(2.5 \mathrm{Y} 4 / 1 \mathrm{~s}) \text {; clay; sub blocks, medium- } \\
\text { large, angular; extremely hard, not plastic and non sticky; gradual wavy transition. }\end{array}$ \\
\hline $\mathbf{B i}_{1}$ & $\begin{array}{l}0.65-1.50 \mathrm{~m} \text {, oliva }(2.5 \mathrm{y} 4 / 3 \mathrm{u}) \text {, variegated coloring dry yellow }(2.5 \mathrm{y} 5 / 3 \mathrm{~s}) \text { yellowish red } \\
(5 \mathrm{YR} 5 / 8 \mathrm{~s}) \text {, black ( } 5 \text { YR } 2.5 / 1 \mathrm{~s}) \text {; franco clay; sub blocks, medium-large, angular; hard, not } \\
\text { plastic, non sticky; abrupt and irregular transition. }\end{array}$ \\
\hline $\mathbf{B i}_{2}$ & $\begin{array}{c}1.50-2.00 \mathrm{~m} \text { olive brown/grayish yellow }(2.5 \mathrm{Y} 4 / 33 / 1 \mathrm{u}) \text {, grayish yellow/ olive brown }(2.5 \mathrm{Y} \\
\text { 4/1 4/4 s); clay; Sub-angular grains, medium-large blocks, strong; very hard, not plastic and non } \\
\text { sticky. }\end{array}$ \\
\hline
\end{tabular}

The CXbe studied has dark gray colors, reaching an almost black coloration on the last horizon with value of 6 when dry and 8 when wet. The transition between horizons ranged from abrupt and gradual and from corrugated to irregular, being well marked by the difference between colors. The structure was along the profile in angular sub blocks medium to large and strong. 
The consistency when dry was hard and the wet consistency could not be observed because the sample moistened externally and not internally, explains Santos et al. (2013). When wet, the soil consistency showed no plasticity and tackiness. Even with higher clay content, plasticity and stickiness may be absent due to the stable arrangement of minerals 1:1 and Fe oxides. The CXbe also presented cohesive character and morphological characteristics similar to the B latosolic; characteristic of this class explains Oliveira (2008).

The profile 2 presented sequence of horizons $\mathrm{A}, \mathrm{AB}$, and $\mathrm{Bw}_{1} \mathrm{Bw}_{2}$ (Table 2), and was classified as "Latossolo Amarelo eutrófico típico (LAe), muito argiloso, A antrópico, caulinítico oxídico, hipoférrico, atividade muito baixa, bem drenado". The transition between horizons was diffuse and corrugated, with little visual distinction between horizons. The structure was observed in blocks that fell apart more easily to the last horizon, reaching granular. The consistency of LAe when dry was hard on the horizontal surface and in loose in the subsequent horizons, when moist the consistency was friable and when wet had a slight stickiness and plasticity in the surface horizons.

Table 2. Morfology of "Latossolo Amarelo eutrófico típico (LAe)" (Oxisol), under degraded pasture.

\begin{tabular}{|c|c|}
\hline Horizon & Depth; color moist; texture; structure; consistence; boundary \\
\hline $\mathbf{A}$ & $\begin{array}{c}0.0-0.29 \mathrm{~m} \text {, brown }(7.5 \mathrm{YR} 4 / 4 \mathrm{u}) \text {, reddish yellow ( } 7.5 \mathrm{YR} 6 / 8 \mathrm{~s}) \text {; clay; sub angular blocks, } \\
\text { medium, moderate; hard, very friable, slightly plastic and slightly sticky; wavy transition and } \\
\text { diffuse. }\end{array}$ \\
\hline $\mathbf{A} / \mathbf{B}$ & $\begin{array}{c}0.29-0.37 \mathrm{~m} \text {, strong brown }(7.5 \mathrm{YR} 5 / 6 \mathrm{u}) \text {, reddish yellow ( } 7.5 \mathrm{YR} 6 / 8 \mathrm{~s}) \text {; very clayish; sub } \\
\text { angular blocks, medium, moderate; soft, very friable, slightly plastic and slightly sticky; flat and } \\
\text { diffuse transition. }\end{array}$ \\
\hline $\mathrm{Bw}_{1}$ & $\begin{array}{l}0.37-0.66 \mathrm{~m} \text {, strong brown }(7.5 \mathrm{YR} 5 / 6 \mathrm{u}) \text {, reddish yellow }(7.5 \mathrm{YR} 6 / 8 \mathrm{~s}) \text {; very visible; Sub- } \\
\text { angular grains blocks, too small, weak; loose, very friable, not plastic and non sticky; flat and } \\
\text { diffuse transition. }\end{array}$ \\
\hline $\mathrm{Bw}_{2}$ & $\begin{array}{l}0.66 \text { - } 1.10 \mathrm{~m}+\text {, strong brown }(7.5 \mathrm{YR} 5 / 6 \mathrm{u}) \text {, reddish yellow }(7.5 \mathrm{YR} 6 / 8 \mathrm{~s}) \text {; very visible; } \\
\text { granular medium-big, strong: loose, very friable, not plastic and no sticky. }\end{array}$ \\
\hline
\end{tabular}

The profile 3 showed morphological characteristics similar to profile 2 , in a sequence of three horizons $\mathrm{A}, \mathrm{A} / \mathrm{B}$ e Bw (Table 3). And has been classified as "Latossolo Vermelho eutrófico chernossólico (LVe), argiloso, A chernozênico, gibbsitico-oxídico, hipoférrico bem drenado". The structure of LVe observed was in weak blocks that easily crumble into granules. The transition was diffuse and corrugated. The dry consistency was hard on the horizon A and soft and loose in the subsequent when wet was very friable and when wet presented slight stickiness and plasticity. The difference between the profiles 2 and 3 was in relation to the colors. The profile 3 showed reddish color along the horizons while the profile 2 showed more yellowing.

\section{Physical attributes}

The CXbe has medium texture in the first horizon and clayey in the horizons $\mathrm{A} / \mathrm{B}, \mathrm{Bi}_{1}$ and $\mathrm{Bi}_{2}$, but without increments of clay for characterization of textural horizon B or eluvial horizon (EMBRAPA, 2013). The LVe also showed the same behavior. However, the LAe presented clayey and very clayey textures at all horizons (Table 4). 
Table 3. Morfology of "Latossolo Vermelho eutrófico chernossólico (LVe)" (Oxisol), under rotate pasture.

\begin{tabular}{|c|c|}
\hline Horizon & Depth; color moist; texture; structure; consistence; boundary \\
\hline $\mathbf{A}$ & $\begin{array}{c}0.0-0.36 \mathrm{~m} \text {, dark reddish brown }(2.5 \mathrm{YR} 2.5 / 4 \mathrm{u}) \text {, red }(2.5 \mathrm{YR} 4 / 8 \mathrm{~s}) \text {; argiloarenosa; angular } \\
\text { blocks, medium, weak; slightly hard, very friable, slightly sticky and slightly plastic; wavy } \\
\text { transition and diffuse. }\end{array}$ \\
\hline $\mathbf{A} / \mathbf{B}$ & $\begin{array}{l}0.36-0.58 \mathrm{~m} \text {, dark red }(2.5 \text { YR } 3 / 6 \mathrm{u}) \text {, red }(2.5 \text { YR } 5 / 8 \mathrm{~s}) \text {; clay; angular blocks, medium, weak; } \\
\text { loose, very friable, slightly sticky and slightly plastic; wavy transition and diffuse. }\end{array}$ \\
\hline $\mathrm{Bw}_{1}$ & $\begin{array}{l}0.58-1.30 \mathrm{~m}+\text {, dark red }(2.5 \mathrm{YR} 3 / 6 \mathrm{u}) \text {, red }(2.5 \mathrm{YR} 5 / 8 \mathrm{~s}) \text {; clay; francossiltosa; very small } \\
\text { blocks the granular, weak; loose, very friable, slightly sticky and slightly plastic. }\end{array}$ \\
\hline
\end{tabular}

Table 4. Physical attributes of the soils studied under native forest, degraded pasture and rotated pasture.

\begin{tabular}{|c|c|c|c|c|c|c|c|c|c|c|}
\hline \multirow[t]{2}{*}{ Depth } & \multirow[t]{2}{*}{ Horizon. } & \multicolumn{3}{|c|}{$\begin{array}{l}\text { Granulometric } \\
\text { composition }\end{array}$} & \multirow[t]{2}{*}{$\mathrm{S} / \mathrm{C}$} & \multicolumn{2}{|c|}{ Density } & \multirow[t]{2}{*}{ Porosity } & \multirow[t]{2}{*}{ PR } & \multirow[t]{2}{*}{ AWC } \\
\hline & & Fine & Silt & Clay & & Bulk & Particle & & & \\
\hline $\mathrm{m}$ & \multicolumn{5}{|c|}{-------g kg-1---------- } & \multicolumn{2}{|c|}{-----mg m ${ }^{-3}-----$} & ------\%----- & $\mathrm{MPa}$ & \\
\hline \multicolumn{11}{|c|}{ “Cambissolo Háplico Tb eutrófico latossólico (CXbe)" (Inceptsol) - NATIVE FOREST } \\
\hline $0-0.25$ & A & 390 & 240 & 370 & 0.65 & 1.42 & 2.47 & 42.49 & 2.63 & 15.61 \\
\hline-0.65 & $\mathrm{~A} / \mathrm{B}$ & 147 & 300 & 553 & 0.54 & 1.61 & 2.47 & 34.75 & 3.12 & 13.68 \\
\hline-1.50 & $\mathrm{Bi}_{1}$ & 327 & 280 & 393 & 0.71 & - & - & - & - & - \\
\hline$-2.00+$ & $\mathrm{Bi}_{2}$ & 260 & 220 & 520 & 0.42 & - & - & - & - & - \\
\hline \multicolumn{11}{|c|}{ "Latossolo Amarelo eutrófico típico (LAe)" (Oxisol) - DEGRADED PASTURE } \\
\hline $0-0.29$ & A & 400 & 80 & 520 & 0.15 & 1.74 & 2.44 & 28.41 & 7.10 & 5.15 \\
\hline-0.37 & $\mathrm{~A} / \mathrm{B}$ & 300 & 80 & 620 & 0.13 & 1.79 & 2.64 & 31.76 & 7.45 & 4.67 \\
\hline-0.66 & $\mathrm{Bw}_{1}$ & 260 & 120 & 620 & 0.19 & - & - & - & - & - \\
\hline$-1.10+$ & $\mathrm{Bw}_{2}$ & 300 & 80 & 620 & 0.13 & - & - & - & - & - \\
\hline \multicolumn{11}{|c|}{ "Latossolo Vermelho eutrófico chernossólico (LVe)" (Oxisol) - ROTATE PASTURE } \\
\hline $0-0.36$ & A & 520 & 120 & 360 & 0.33 & 1.51 & 2.33 & 35.27 & 10.89 & 3.57 \\
\hline-0.58 & $\mathrm{~A} / \mathrm{B}$ & 360 & 120 & 520 & 0.23 & - & - & - & - & - \\
\hline$-1.30+$ & $\mathrm{Bw}_{1}$ & 400 & 50 & 550 & 0.09 & - & - & - & - & - \\
\hline
\end{tabular}

RP: Resistence penetration. S/C: silt/clay.

It was observed that the LVe and LAe showed lower silt relative to CXbe referencing the age of the soil. Anjos et al. (2007) observed higher silt in "Plintossolos", assigning these levels to weathering processes, which are less significant in some classes, such as the "Cambissolos" and "Plintossolos". Pereira et al. (2010) even claim that the amount of silt can also refer to the soil parent material.
Most silt/clay ratio ( $\mathrm{s} / \mathrm{c})$ was observed in CXbe, values compatible with the process of soil weathering as well as "Latossolos", as suggested by Embrapa (2013). Souza et al. (2010) observed values of relation s/a similar to those found for "Cambissolos Háplicos $\mathrm{Tb}$ eutróficos típico e latossólico" in the state of Pernambuco. 
All the studied profiles showed bulk density (BD) above $1.42 \mathrm{Mg} \mathrm{m}^{-3}$ (Table 4). In the CXbe the $\mathrm{BD}$ and the soil resistance to penetration (PR) were lower in the horizon A and higher in the horizon A/B. The total porosity behaved conversely, larger on the horizon A and lower in the horizon $\mathrm{A} / \mathrm{B}$, as expected.

The LAe showed the higher averages of BD and PR and lower total porosity and available water capacity. Results that show the greatest soil compaction, which probably gave up the use of extensive grazing without specific care for the physical management of the soil. The pasture on the soil already studied showed some stage of degradation, having no green matter content suitable for maintaining the organic matter content in amounts that can contribute to physical improvement of the soil.

The LVe showed lower values of $\mathrm{BD}$ and PR in relation to LAe. These results may be related to the management system adopted for this soil under rotated pasture. This management system is no greater concern for stocking rate, occupancy period, height of the pasture for entry of animals, and other features that contribute to the improvement of soil cover, which can promote their physical and chemical quality. Fernandes et al. (2014) while studying different grazing management systems observed that rotated pasture is an alternative that ensures the forage production in the system and promotes physical improvement of soil compared to the extensive grazing system.

Santos et al. (2010) also observed high levels of BD when studying "Cambissolos", "Argissolos" and "Gleissolos". According to the authors, the $\mathrm{BD}$ it is closely related to the levels of OM of the soil. When comparing the values of $\mathrm{BD}$ and $\mathrm{PR}$ of CXbe under forest and LVe under rotated pasture is observed similar values, while the LAe under degraded pasture values are much higher than the previous two. Thus, it can be understood that rotated pasture is a form of management that benefits the soil by the proportion of larger vegetation cover.

\section{Chemical attributes}

The CXbe showed $\mathrm{pH}$ strongly acid on the horizon A and moderately acid in the other horizons (EMBRAPA, 2013), as can be observed in Table 5. The LAe showed $\mathrm{pH}$ moderately acid in surface (Horizon A) and strongly acidic in subsurface. And the LVe showed $\mathrm{pH}$ moderately acid in all horizons. One should consider that the profile under forest (CXbe) has a large amount of organic material to suffer degradation processes releases numerous $\mathrm{H}+$ ions that contribute to acidification in surface.

The LVe even showing $\mathrm{pH}$ in the same range in all horizons, there is a slight acidification in the subsurface, as well as LAe. Anjos et al. (2007) explain that the deep increase in acidity is due to Pedogenic processes such as ferrolic, causing changes in the $\mathrm{pH}$. You can also associate this $\mathrm{pH}$ range to the decomposition of $\mathrm{OM}$, nutrient uptake by the roots, releasing $\mathrm{H}^{+}$ions and similar. In the profile Lve, under rotated pasture should be considered that are adopted some management practices, such as liming and fertilization that interfere in the soil $\mathrm{pH}$.

The results of $\mathrm{pH} \mathrm{H}_{2} \mathrm{O}$ were higher than those observed in $\mathrm{CaCl}_{2}$, demonstrating predominance of negative charges in the studied "Latossolos" and "Cambissolos". Pereira et al. (2010) also made the same considerations when studying the same soil classes.

In none of the profiles was observed amount of $\mathrm{Al}^{3+}$ to determine to the soils, aluminic and alitic character (EMBRAPA, 2013). Only the horizon A/B of the CXbe presented $0.03 \mathrm{cmol}_{\mathrm{c}} \mathrm{dm}^{-3}$ of $\mathrm{Al}^{3+}$ and $0.43 \%$ of saturation by aluminum and the horizon $\mathrm{A}$ of the LAe with $3 \mathrm{cmol}_{\mathrm{c}} \mathrm{dm}^{-3}$ of $\mathrm{Al}^{3+}$ and $7.75 \%$ of saturation by aluminum. The CXbe was the soil that presented a greater potential acidity, above $3 \mathrm{cmol}_{\mathrm{c}}$ $\mathrm{dm}^{-3}$. The LAe showed similar values in horizons $\mathrm{A}$ and $\mathrm{A} / \mathrm{B}$, in other horizons values were below $2 \mathrm{cmol}_{\mathrm{c}} \mathrm{dm}^{-3}$. The LVe showed values lower than 2 $\mathrm{cmol}_{\mathrm{c}} \mathrm{dm}^{-3}$ of $\mathrm{Al}^{3+}$ in all the horizons. 
Table 5. Chemical attributes of the soils studied under native forest, degraded pasture and rotated pasture.

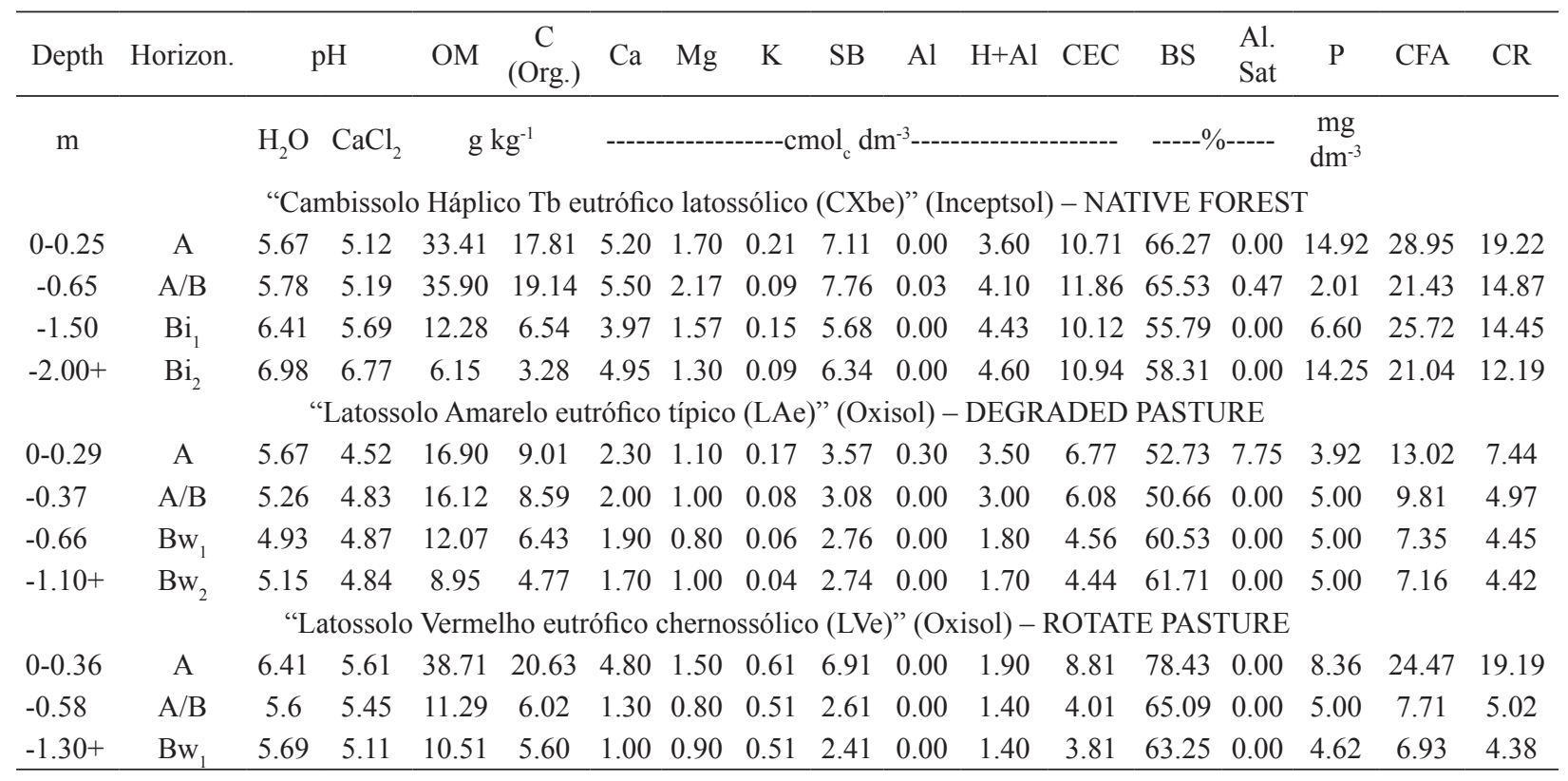

OM: organic matter; C:organic carbon; SB: sum of bases; BS: base saturation; Al. sat.: percentage of Al saturation; CFA: clay fraction activity; CR: cation retention.

The profile under forest (CXbe) was the one with higher OM content in horizons $\mathrm{A}$ and $\mathrm{A} / \mathrm{B}$, with low values on others. The horizon of LVe also showed high OM content, reinforcing the previously mentioned, due to the amount of vegetation cover there is a greater deposition of OM. The other horizons of LVe and LAe had low levels, close to $17 \mathrm{~g} \mathrm{~kg}^{-1}$. Araújo et al. (2009) observed that "Cambissolos" have higher OM content.

The CXbe showed SB higher than $5 \mathrm{cmol}_{\mathrm{c}} \mathrm{dm}^{-3}$ in all horizons and greater than $7 \mathrm{cmol}_{\mathrm{c}} \mathrm{dm}^{-3}$ in the first horizons. In all the horizons, the $\mathrm{Ca}^{2+}$ followed by the $\mathrm{Mg}^{2+}$ were the main contributors on the complex of basis, presenting a relation $\mathrm{Ca}: \mathrm{Mg}$ around $3: 1$. The soil CEC was also high in all horizons, greater than $10 \mathrm{cmol}_{\mathrm{c}} \mathrm{dm}^{-3}$. The BS was classified as eutrophic along the profile (EMBRAPA, 2013) all are above $55 \%$.

Santos et al. (2010) studying a "Cambissolos" observed high BS, with greater contribution of $\mathrm{Mg}^{2+}$. Anjos et al. (2007) explain that the greatest contribution of $\mathrm{Ca}^{2+}$ or $\mathrm{Mg}^{2+}$ occurs depending on the source material. Souza et al. (2007) studying a "Cambissolo Háplico Tb eutrófico latossólico" found results similar to those found in this, high BS with the highest contribution of $\mathrm{Ca}^{2+}$.

The LAe presented lower SB, CEC and BS than the CXbe, while the LVe presented higher values and closer to the values observed in CXbe in the horizon A, showing the influence of the larger amount of OM on this. In the LVe the BS was above $63 \%$ throughout the profile, reaching $78 \%$ in the horizon A whereas the need for BS of pastures, studied "Latossolos" require no adjustment for this attribute (RAIJ et al., 1997).

Only the LVe showed values of $\mathrm{K}^{+}$higher than $0.50 \mathrm{cmol}_{\mathrm{c}} \mathrm{dm}^{-3}$. The other profiles showed values below $0.20 \mathrm{cmol}_{\mathrm{c}} \mathrm{dm}^{-3}$. Pereira et al. (2010) also observed low values of $\mathrm{K}^{+}$while studying "Cambissolos" and "Latossolos" developed under substrate of pelitic rock.

The $\mathrm{P}$ levels were higher in the CXbe in the horizons $\mathrm{A}$ and $\mathrm{Bi}_{2}$ above $14 \mathrm{mg} \mathrm{dm}^{-3}$. In the horizons $\mathrm{A} / \mathrm{B}$ e $\mathrm{Bi}_{1}$ the levels were of 2.02 and 
$6.60 \mathrm{mg} \mathrm{dm}^{-3}$, respectively. Probably the difference in the availability of $\mathrm{P}$ can be explained by the predominant mineral and the amount of OM. LAe in the lower availability of $\mathrm{P}$ was observed in the horizon A, $3.92 \mathrm{mg} \mathrm{dm}^{-3}$, the others presented 5.00 $\mathrm{mg} \mathrm{dm}{ }^{-3}$. The LVe showed higher $\mathrm{P}$ availability to the horizon A, $8.36 \mathrm{mg} \mathrm{dm}^{-3}$, which decreased in depth, $5.00 \mathrm{mg} \mathrm{dm}^{-3}$ for the horizon A/B e $4.62 \mathrm{mg}$ $\mathrm{dm}^{-3}$ for the horizon Bw.

Souza et al. (2010) state that higher part of the P to "Latossolos" is not in labile form, which reduces their availability, causing the deficiencies. The availability of $\mathrm{P}$ is also related with the soil source material. Pereira et al. (2010) studying "Cambissolos" and "Latossolos" of pelitic origin, observed low levels of $\mathrm{P}$ to soils.

The CXbe has clay fraction activity (CFA) higher in the horizon A, higher than $27 \mathrm{cmol}_{\mathrm{c}} \mathrm{kg}^{-1}$ and CFA low in other horizons (EMBRAPA, 2013). However, the values are still high, above $20 \mathrm{cmol}_{\mathrm{c}}$ $\mathrm{kg}^{-1}$, but it is still classified as Tb. The LAe showed CFA low in all horizons being less than $17 \mathrm{cmol}_{\mathrm{c}} \mathrm{kg}^{-}$ 1, diagnostic attribute, for classifying the latosolic horizon B (EMBRAPA, 2013).

The LVe showed CFA higher than $17 \mathrm{cmol}_{\mathrm{c}} \mathrm{kg}^{-1}$ in the horizon $\mathrm{A}$ and lower than $8 \mathrm{cmol}_{\mathrm{c}} \mathrm{kg}^{-1}$ on the other horizons. The retention of cations followed the CFA, higher in CXbe and in the horizon A of the LVe and around 4.00-5.00 on the other horizons and in the LAe. It was observed that the CXbe has greater natural fertility and the horizon $\mathrm{A}$ of LVe has characteristics similar to CXbe, likely effect of management practices, while in LAe there is no management practices and pasture already degraded.
Crystalline and not-crystalline iron and sulfuric Attack

In Table 6 are shown the values of $\mathrm{Fe}_{\mathrm{o}}$ and $\mathrm{Fe}_{\mathrm{d}}$ and the relation $\mathrm{Fe}_{\mathrm{o}} / \mathrm{Fe}_{\mathrm{d}}$. It can be observed that the values of $\mathrm{Fe}_{\mathrm{d}}$ in the CXbe varied from $19.00-29.00$ $\mathrm{g} \mathrm{kg}^{-1}$, while in other profiles there was a greater quantity of $\mathrm{Fe}_{\mathrm{d}}$, which is the most crystalline form of Fe. To LAe the change was of $26.00-43.00 \mathrm{~g} \mathrm{~kg}^{-1}$ and for the LVe between $29.00-38.00 \mathrm{~g} \mathrm{~kg}^{-1}$. It is also observed that the levels of $\mathrm{Fe}_{\mathrm{o}}$, less crystalline iron is greater in the CXbe, between $7.00-21.00$ $\mathrm{g} \mathrm{kg}^{-1}$, and in the two "Latossolos" which varied between $1.00-8.00 \mathrm{~g} \mathrm{~kg}^{-1}$.

In general, the levels of $\mathrm{Fe}_{\mathrm{o}}$ and $\mathrm{Fe}_{\mathrm{d}}$ are still low corroborating the work of Lima Neto et al. (2010) under "Latossolo Amarelo" and Silva Neto et al. (2008) and Vendrame et al. (2011) to "Latossolo Vermelho" explaining that in addition to soil the old source material interferes with the availability of $\mathrm{Fe}$.

The relation $\mathrm{Fe}_{\mathrm{o}} / \mathrm{Fe}_{\mathrm{d}}$, was also greater in CXbe, above 0.40 in all horizons, while in the "Latossolos" the relation did not exceed 0.30 . These results show the degree of weathering of the soil. Even these soils occurring in relatively close locations, it was seen that in flatter places, the weathering was more intense, favoring the formation of "Latossolos". According to Inda Junior and Kampf (2005) the low results of the relation $\mathrm{Fe}_{\mathrm{o}} / \mathrm{Fe}_{\mathrm{d}}$ are characteristics of the latosolic samples. The results for the relation $\mathrm{Fe}_{\mathrm{o}} / \mathrm{Fe}_{\mathrm{d}}$ are also consistent with those obtained by Ghidin et al. (2006), Inda Junior and Kampf (2003) and Silva Neto et al. (2008), studying "Latossolos".

It is observed that the relation $\mathrm{Fe}_{\mathrm{o}} / \mathrm{Fe}_{\mathrm{d}}$ was higher in the surface in the CXbe and in the LVe. Anjos et al. (2007) attribute these results the greatest amount of $\mathrm{OM}$ on the surface, which contributes to a reduction in crystallinity, showing the interference of vegetation in Pedogenic processes. Camargo et al. (2008) also cites the OM as crystallization inhibitor of iron oxides. 
Table 6. Analysis of crystalline, not crystalline irons and sulfuric attack of the soils studied under native forest, degraded pasture and rotated pasture.

\begin{tabular}{|c|c|c|c|c|c|c|c|c|c|c|}
\hline Depth & Horizon. & $\mathrm{Fe}_{\mathrm{d}}$ & $\mathrm{Fe}_{\mathrm{o}}$ & $\mathrm{Fe}_{\mathrm{o}} / \mathrm{Fe}_{\mathrm{d}}$ & $\mathrm{SiO}_{2}$ & $\mathrm{Al}_{2} \mathrm{O}_{3}$ & $\mathrm{Fe}_{2} \mathrm{O}_{3}$ & $\mathrm{Ki}$ & $\mathrm{Kr}$ & $\begin{array}{c}\mathrm{Al}_{2} \mathrm{O}_{3} \\
\mathrm{Fe}_{2} \mathrm{O}_{3}\end{array}$ \\
\hline \multicolumn{11}{|c|}{ 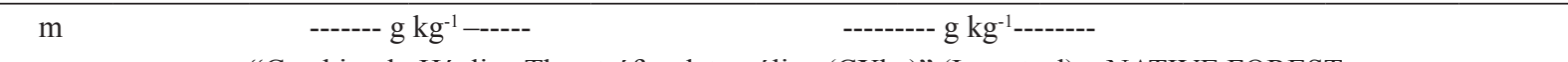 } \\
\hline \multicolumn{11}{|c|}{ "Cambissolo Háplico Tb eutrófico latossólico (CXbe)" (Inceptsol) - NATIVE FOREST } \\
\hline $0-0.25$ & A & 19.324 & 17.054 & 0.883 & - & - & - & - & - & - \\
\hline-0.65 & $\mathrm{~A} / \mathrm{B}$ & 29.799 & 21.542 & 0.723 & & - & - & - & - & - \\
\hline-1.50 & $\mathrm{Bi}_{1}$ & 24.200 & 7.344 & 0.303 & 116 & 90 & 59.05 & 2.2 & 0.4 & 1.52 \\
\hline$-2.00+$ & $\mathrm{Bi}_{2}$ & 42.080 & 18.686 & 0.444 & - & - & - & - & - & - \\
\hline \multicolumn{11}{|c|}{ "Latossolo Amarelo eutrófico típico (LAe)" (Oxisol) - DEGRADED PASTURE } \\
\hline $0-0.29$ & A & 27.271 & 2.040 & 0.075 & - & - & - & - & - & - \\
\hline-0.37 & $\mathrm{~A} / \mathrm{B}$ & 26.006 & 2.122 & 0.082 & - & - & - & - & - & - \\
\hline-0.66 & $\mathrm{Bw}_{1}$ & 33.411 & 7.018 & 0.210 & 101.5 & 85 & 40.5 & 2.0 & 0.4 & 2.10 \\
\hline$-1.10+$ & $\mathrm{Bw}_{2}$ & 43.705 & 1.714 & 0.039 & - & - & - & - & - & - \\
\hline \multicolumn{11}{|c|}{ "Latossolo Vermelho eutrófico chernossólico (LVe)" (Oxisol) - ROTATE PASTURE } \\
\hline $0-0.36$ & A & 29.077 & 8.078 & 0.278 & - & - & - & - & - & - \\
\hline-0.58 & $\mathrm{~A} / \mathrm{B}$ & 38.107 & 1.224 & 0.032 & 25.5 & 170 & 44.07 & 0.3 & 0.1 & 3.86 \\
\hline$-1.30+$ & $\mathrm{Bw}_{1}$ & 36.662 & 2.366 & 0.065 & - & - & - & - & - & - \\
\hline
\end{tabular}

$\mathrm{Fe}_{\mathrm{o}}$ : iron extracted by ammonium oxalate; $\mathrm{Fe}_{\mathrm{d}}$ : iron oxides extracted by dithionite-bicarbonate-citrate.

The total levels of Fe, $\mathrm{Al}$ and $\mathrm{Si}$ were analyzed only for the horizon $\mathrm{B}$, diagnosis that requires $\mathrm{Ki}$ and $\mathrm{Kr}$ indexes in its classification. Regarding the levels of $\mathrm{Fe}_{2} \mathrm{O}_{3}$, following the Embrapa (2013) classification the profiles were classified as hypoferric, presenting levels of $\mathrm{Fe}_{2} \mathrm{O}_{3}$, lower than $80 \mathrm{~g} \mathrm{~kg}^{-1}$. It was observed that the CXbe showed the greatest amount of $\mathrm{SiO}_{2}$ and the $\mathrm{LVe}$ the greatest amount of $\mathrm{Al}_{2} \mathrm{O}_{3}$ (Table 6). Silva et al. (2011) they also worked with soils of low Fe content classified as hypoferric in Amazonas State. Ghidin et al. (2006) explain that the greatest amount of $\mathrm{SiO}_{2}$ in the CXbe and in the LVe and LAe can refer to the soil source material.

The higher $\mathrm{Ki}$ values were found in CXbe and LAe, 2.20 and 2.00 respectively, demonstrating the high contribution of $\mathrm{SiO}_{2}$ in this index. The $\mathrm{Kr}$ was 0.40 for two profiles. In the LVe the $\mathrm{Ki}$ was 0.30 and the $\mathrm{Kr}$ 0.10. These indices classified the soils as oxidic kaolinitic (CXbe and LAe) and oxidic gibbsitic (LVe). Santos et al. (2010) and Souza et al. (2010) found values of Ki very close to those found for "Cambissolos Háplicos". Ghidin et al. (2006) claim that the index reinforces the soil weathering process.

\section{Mineralogical attributes: (Kt) Kaolinite and Gibbsite (Gb)}

It could be observed that the surface area of the $\mathrm{Kt}$ is higher than $\mathrm{Gb}$ for the CXbe and the LAe, except for the horizon $\mathrm{Bi}_{1}$ of the CXbe (Table 7). In the LVe was observed that there is inversion in this result, i.e., the surface area of $\mathrm{Gb}$ is higher than $\mathrm{Kt}$ due to $\mathrm{Gb}$ be a predominant in the soil, contrary to the previous two. 
Table 7. Crystallographic data of the minerals kaolinite and gibbsite soils studied under native forest, degraded pasture and rotated pasture.

\begin{tabular}{|c|c|c|c|c|c|c|c|c|}
\hline Depth & Horizon. & $\begin{array}{c}\mathrm{Kt} / \\
(\mathrm{Kt}+\mathrm{Gb})\end{array}$ & $\mathrm{ÁREA}_{\mathrm{Kt}}$ & ÁREA $_{\mathrm{Gb}}$ & $\mathrm{WHH}_{\mathrm{Kt}}$ & $\mathrm{WHH}_{\mathrm{Gb}}$ & $\mathrm{MDC}_{\mathrm{Kt}}$ & $\mathrm{MDC}_{\mathrm{Gb}}$ \\
\hline $\mathrm{m}$ & & & & & \multicolumn{2}{|c|}{--------2º------- } & \multicolumn{2}{|c|}{--------nm------- } \\
\hline \multicolumn{9}{|c|}{ “Cambissolo Háplico Tb eutrófico latossólico (CXbe)” (Inceptsol) - NATIVE FOREST } \\
\hline $0-0.25$ & A & 0.841 & 98.42 & 18.65 & 0.353 & 0.055 & 23.689 & 152.432 \\
\hline-0.65 & $\mathrm{~A} / \mathrm{B}$ & 0.759 & 200.00 & 63.55 & 0.420 & 0.420 & 19.890 & 20.027 \\
\hline-1.50 & $\mathrm{Bi}_{1}$ & 0.371 & 133.48 & 226.05 & 0.383 & 0.128 & 21.789 & 65.518 \\
\hline$-2.00+$ & $\mathrm{Bi}_{2}$ & 0.865 & 191.44 & 29.98 & 0.403 & 0.071 & 20.698 & 118.224 \\
\hline \multicolumn{9}{|c|}{ "Latossolo Amarelo eutrófico típico (LAe)" (Oxisol) - DEGRADED PASTURE } \\
\hline $0-0.29$ & A & 0.753 & 114.86 & 37.72 & 0.345 & 0.167 & 24.241 & 50.293 \\
\hline-0.37 & $\mathrm{~A} / \mathrm{B}$ & 0.766 & 116.39 & 35.54 & 0.446 & 0.085 & 18.727 & 98.457 \\
\hline-0.66 & $\mathrm{Bw}_{1}$ & 0.829 & 147.99 & 30.56 & 0.319 & 0.150 & 26.216 & 56.035 \\
\hline$-1.10+$ & $\mathrm{Bw}_{2}$ & 0.696 & 144.93 & 63.4 & 0.486 & 0.095 & 17.170 & 88.464 \\
\hline \multicolumn{9}{|c|}{ "Latossolo Vermelho eutrófico chernossólico (LVe)" (Oxisol) - ROTATE PASTURE } \\
\hline $0-0.36$ & A & 0.361 & 116.22 & 205.33 & 0.276 & 0.120 & 30.249 & 69.904 \\
\hline-0.58 & $\mathrm{~A} / \mathrm{B}$ & 0.343 & 117.8 & 225.62 & 0.419 & 0.122 & 19.947 & 68.705 \\
\hline$-1.30+$ & $\mathrm{Bw}_{1}$ & 0.348 & 84.12 & 157.33 & 0.413 & 0.088 & 20.231 & 95.586 \\
\hline
\end{tabular}

Kt: Kaolinite; Gb: Gibbsite; WHH: width at half height; MDC - mean crystallite dimension.

The relation $\mathrm{Kt} /(\mathrm{Kt}+\mathrm{Gb})$ is higher in $\mathrm{CXbe}$ and LAe, showing higher values than 0.600 indicating the prevalence of Kt on these soils, compared to LVe as predominantly $\mathrm{Gb}$, as shown by the diffratograms illustrated in Figure 2. The predominance of minerals such as $\mathrm{Kt}$, due to its structural formation prints to the ground greater density, as can be noted in previous discussions. Gomes et al. (2004a) studying clay and very clay "Latossolos" in the states of Goias and Minas Gerais, observed that the highest ratio $\mathrm{Kt} /(\mathrm{Kt}+\mathrm{Gb})$ presents a great coincidence with the dense granular structure.

The relation $\mathrm{Kt} /(\mathrm{Kt}+\mathrm{Gb})$ in the $\mathrm{LVe}$ was lower than 0.40 in all horizons, pointing predominance of Gb. Curi and Franzmeier (1984) claim that the predominance of $\mathrm{Gb}$, especially in depth, as observing the horizon $\mathrm{Bi}_{1}$ of the CXbe, is caused by the removal of $\mathrm{Si}$ or according to the source material.
The WHH of the Kt was higher in all the studied profiles and, similarly, the MDC of the Gb was also higher. These results show the greatest degree of crystallinity of $\mathrm{Gb}$ and corroborate with the results obtained by Camargo et al. (2008) and Ghidin et al. (2006) to "Latossolos Vermelhos eutróficos e distróficos" respectively. Both reported higher degree of crystallinity of $\mathrm{Gb}$ and predominance of it in horizons of "Latossolo Vermelho", as observed in this study.

This way it can see that the CXbe and LAe have mineralogical characteristics that favor the consolidation of soils. Soils with Kt predominance have greater adjustment face to face of the mineral contributing to the consolidation (LIMA NETO et al., 2010). Therefore, attention should be paid to the physical management of these soils opting for techniques that improve soil restructuring and deposition of OM. 
Figure 2. X-ray difratogramas for the minerals of kaolinite $(\mathrm{Kt})$ and gibbsite $(\mathrm{Gb})$ studied profile s P1 - profile 1 ("CXbe - Cambissolo Háplico Tb eutrófico latossólico"; Inceptsol); P2 - profile 2 ("Lae - Latossolo Amarelo eutrófico típico"; Oxisol); and P3 - profile 3 (“LVe - Latossolo Vermelho eutrófico chernossólico" Oxisol).
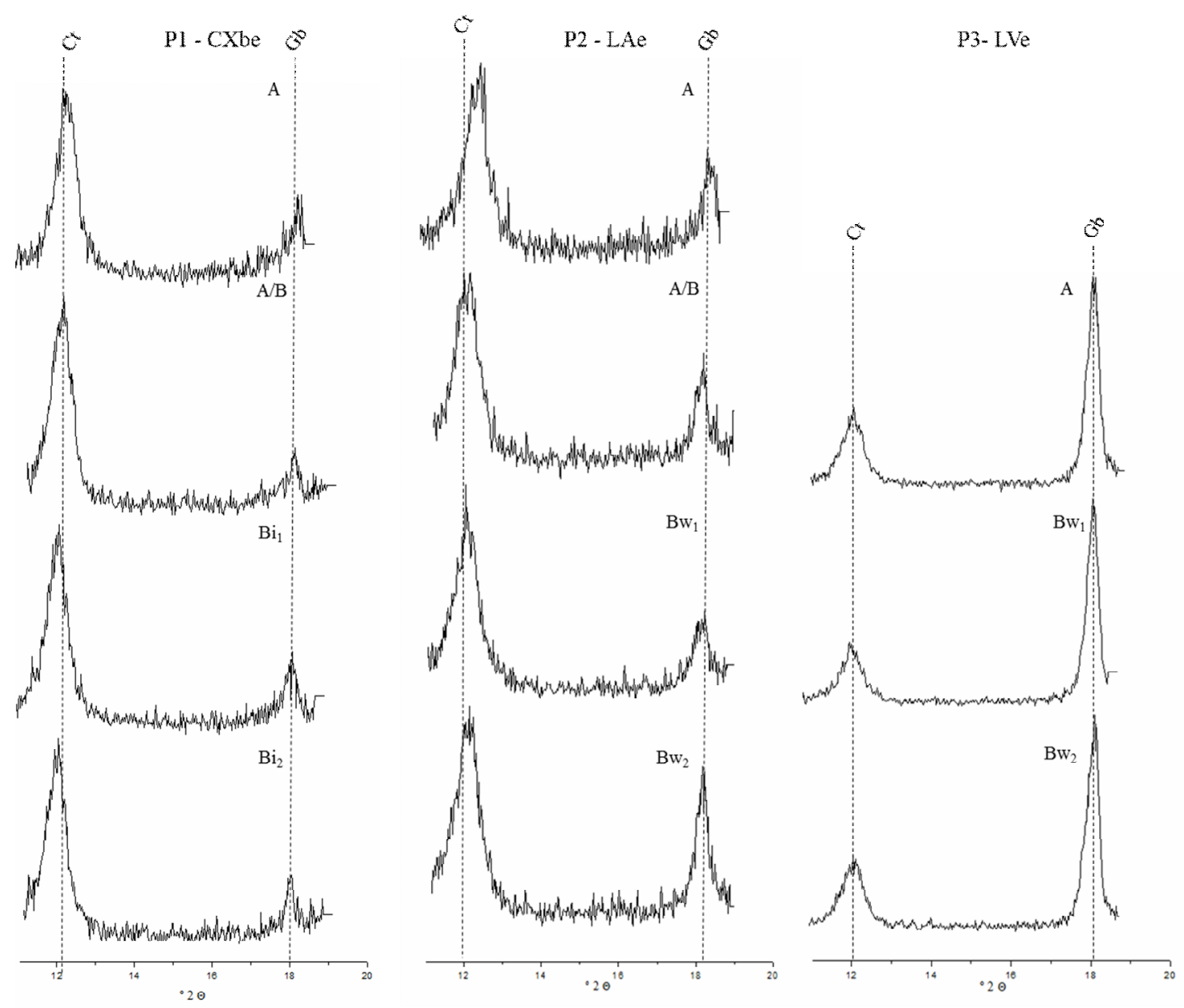

Mineralogical attributes: (Hm) Hematite and Goethite (Gt)

Gt. To the LAe showed a predominance of Gt in the horizons $\mathrm{A}$ and $\mathrm{Bw}_{2}$ and of $\mathrm{Hm}$ in the horizons $\mathrm{A} / \mathrm{B}$ and $\mathrm{Bw}_{2}$. In the LVe showed a predominance of $\mathrm{Gt}$

In the $\mathrm{CX}$ be for the horizons $\mathrm{A}, \mathrm{A} / \mathrm{B}$ and $\mathrm{Bi}_{1}$, there was a predominance of the mineral $\mathrm{Hm}$ over $\mathrm{Gt}$ and on the last horizon, $\mathrm{Bi}_{2}$ showed a predominance of in all the horizons (Table 8, Figure 3). The relation $\mathrm{Gt} /(\mathrm{Gt}+\mathrm{Hm})$ is consistent with these results. 
Figure 3. X-ray difratogramas for the minerals of hematite $(\mathrm{Hm})$ and goethite $(\mathrm{Gt})$ studied profile s P1 - profile 1 ("CXbe - Cambissolo Háplico Tb eutrófico latossólico"; Inceptsol); P2 - profile 2 ("Lae - Latossolo Amarelo eutrófico típico"; Oxisol); and P3 - profile 3 ("LVe - Latossolo Vermelho eutrófico chernossólico" Oxisol).

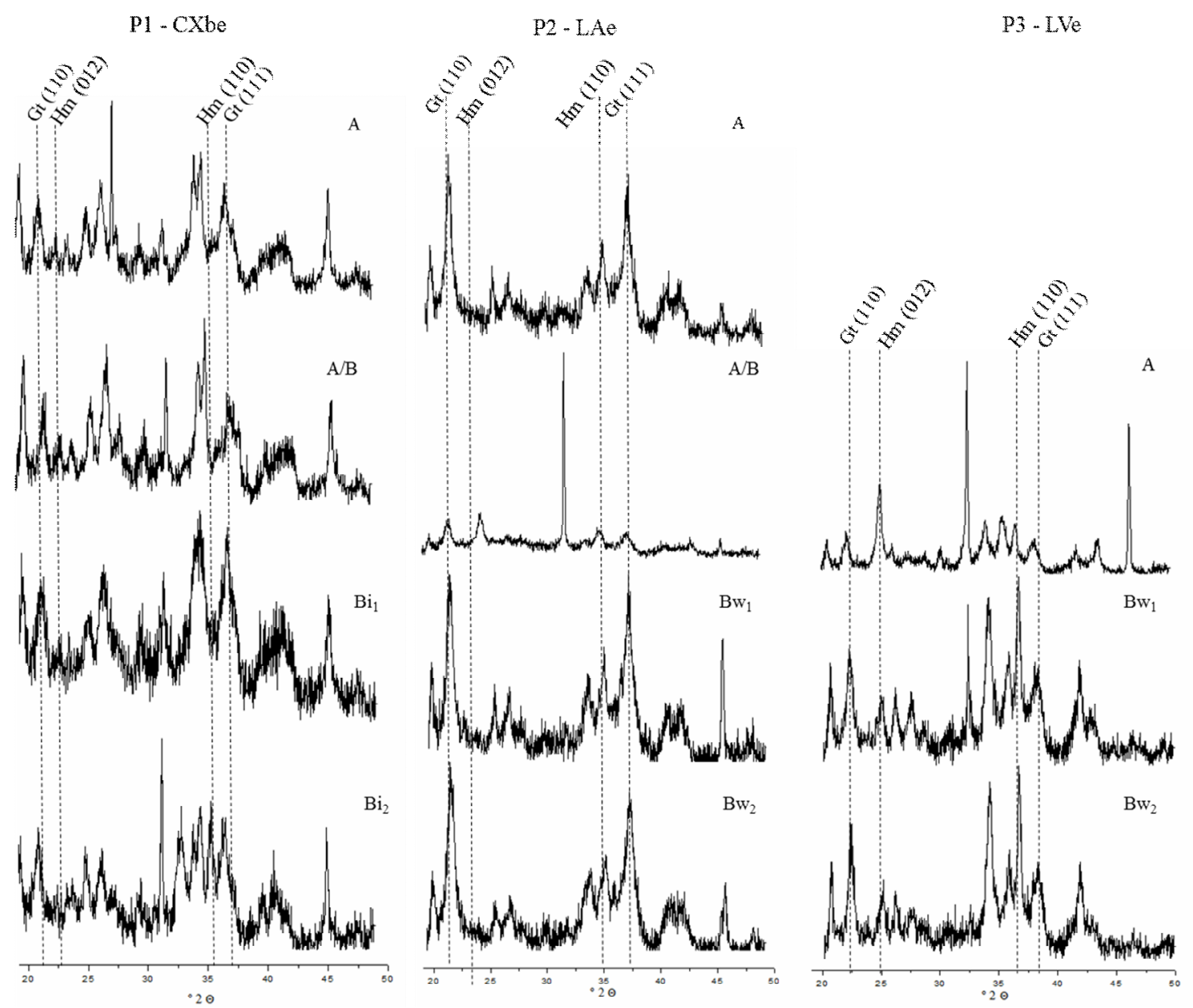




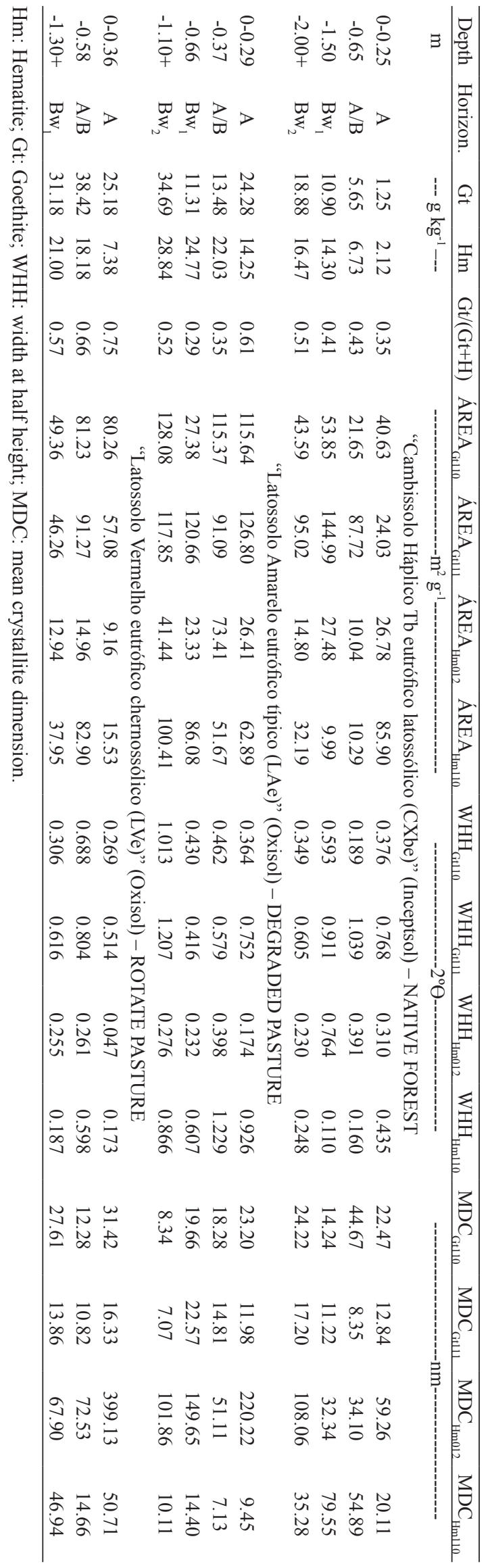

In this case, the procedure $\mathrm{Fe}_{\mathrm{d}}, \mathrm{DBC}_{20}$ (stirring for $16 \mathrm{~h}$ at room temperature), may have influenced the results of Hm and Gt. Inda Junior and Kamf (2003) explain that this procedure is as efficient as the method $\mathrm{DBC}_{80}$ (Controlled temperature water bath for 4 hours). However, in soils with higher amount of Gt and with high isomorphous replacement the extraction by the method used in it, is decreased, influencing the final results.

The levels of Hm and Gt can also be observed in Figure 3. The identification of the peaks of minerals by diffratograms was difficult due to the proximity of the peaks and due to the high isomorphic replacement. Ghidin et al. (2006) also had the same difficulties while studying Fe oxides of "Latossolos" in the state of Paraná.

The surface area of Gt peaks (110 and 111) are larger than the surface area of $\mathrm{Hm}$ (012 and 110). It was observed that there was a decrease in CXbe surface the area of Gt (110) in depth, while the Gt (111) was increased. There were no similar behavior in other profiles. It is known that the $\mathrm{MO}$, the availability of water and microbiological activity, are attributes that influence in the environment of dissolution and remobilization of $\mathrm{Fe}$ oxides, and the vegetation cover of the utmost importance in influencing the pedogenic environment and in the amendment of it (INDA et al., 2013; ZANELLI et al., 2007).

The WHH of the Gt (110) was higher than Gt (111) and the WHH of the Hm It was lower than the Gt to the CXbe. The LAe Showed the same behavior, but the range of values was higher, reaching WHH around 1.000 to the peaks of the Gt and the HM (110). The LVe also showed similar results, with shorter intervals. The WHH lower of the Hm highlights the higher crystallinity of the mineral.

The MDC showed no increasing behavior for any of the profiles. It is noted, however, that the MDC of the Hm is higher of the Gt in both reflexes. The MDC is the expression of habit of the 
mineral growth. Higher values of Gt in the direction (111) relative to the direction (110), for example indicate the mineral circular format (RODRIGUES NETTO, 1996). This behavior was observed only on the horizon $\mathrm{Bw}_{1}$ of the LAe. Similar results were observed by Ghidin et al. (2006).

\section{Principal component analysis}

In the Figure 4 is expressed the main component analysis for the profiles. It is observed that for surface and subsurface horizon profiles were divided into 2 groups: Group 1, in which the properties were grouped around the profiles 2 and 3, "Latossolos" under degraded pasture and under rotated pasture and Group 2 in which the properties were grouped around the profile 1, "Cambissolo" under native forest (CXbe).

Group 1 to the surface horizons, grouped the levels of clay, $\mathrm{Hm}$, Gt and $\mathrm{Fe}_{\mathrm{d}}$, highlighting the similar age of soils, which have higher levels of clay, iron oxides and more crystalline iron. Gomes et al. (2004b) studying Minas Gerais and Goias soils, observed the grouping of minerals, mainly gibbsite, was higher for the Goias State soils under Cerrado formation. Group 1 also included the highest values of $\mathrm{BD}$ and $\mathrm{PR}$, i.e. the soils under pasture management system, whether extensive or rotated, contributing to greater soil compaction compared to the soil under native forest.

Figure 4. Análise de componentes principais, para os horizontes superficiais e subsuperficiais dos perfis estudados. P1 - perfil 1 (CXbe- Cambissolo Háplico Tb eutrófico latossólico); P2 - perfil 2 (LAe-Latossolo Amarelo eutrófico típico); e P3 - perfil 3 (LVe-Latossolo Vermelho eutrófico chernossólico).

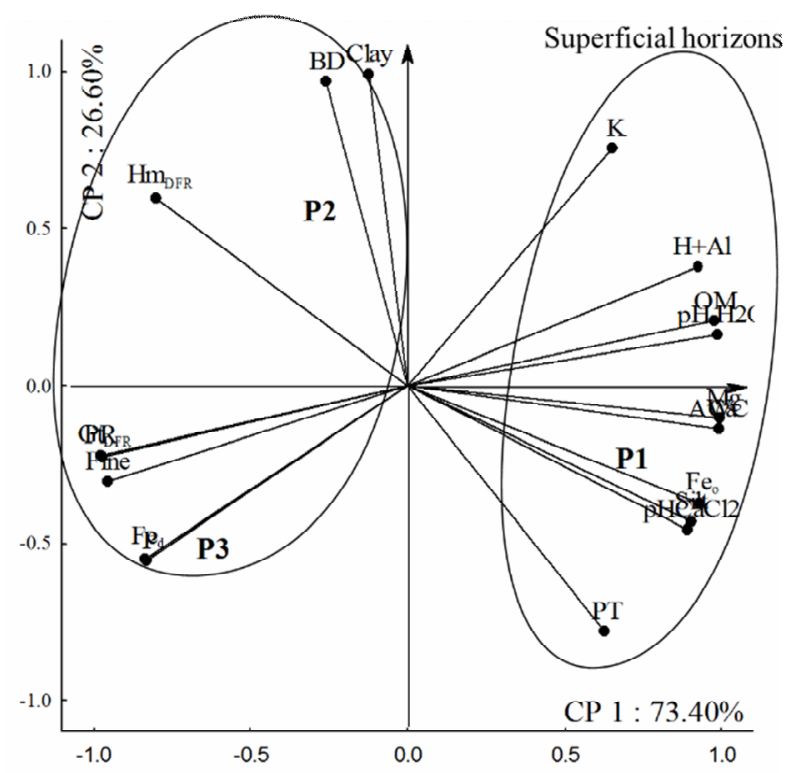

Group 2 grouped the fertility properties, $\mathrm{Ca}^{2+}$, $\mathrm{Mg}^{2+} \mathrm{e} \mathrm{K}^{+}, \mathrm{pH}$ and $\mathrm{OM}$, exposing the best chemical condition of the soil under forest. It should be considered that the profile of forest conditions are natural, existing roots, leaves and other material on the soil surface that affect these better conditions.

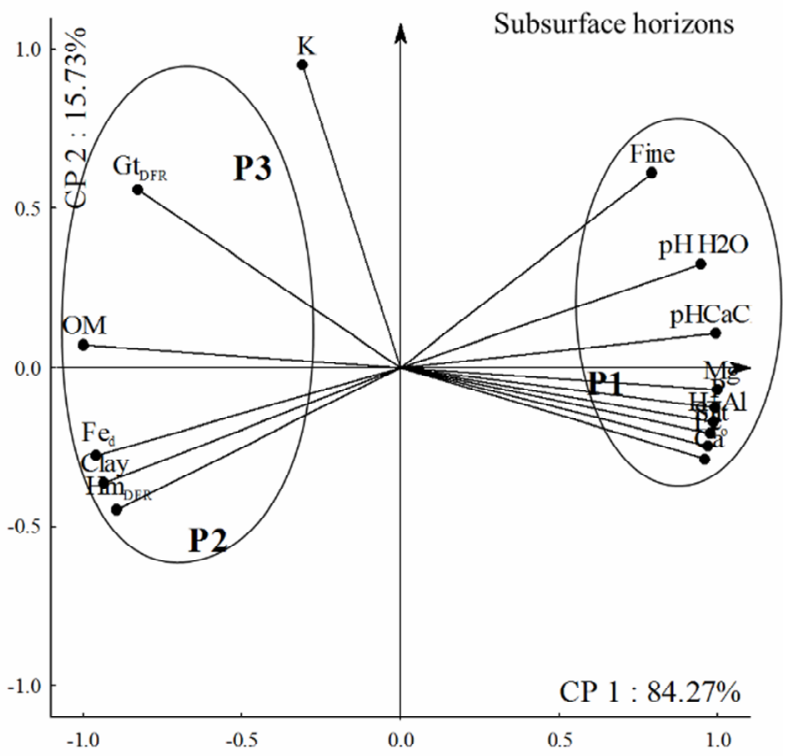

Gomes et al. (2004b) studying the grouping variables of soils of the state of Goias and Minas Gerais, they found that the greater amount of exchangeable bases are grouped next to the profiles under forest formation (Minas Gerais), when compared to the profiles under Cerrado. The authors explain that the 
forest formation is more favorable for the recycling of nutrients.

Group 2 also group the properties PT and AWC. Conditions for water storage in soil under forest are more favorable than in soils under pasture in this profile averages of $\mathrm{BD}$ and $\mathrm{PR}$ is consequently lower, the physical quality is better. Also befitting the highest content of soil's OM. Gomes et al. (2004b) observed that soil water retention and positively correlated with organic carbon factors for soils of Goias and Minas Gerais. The silt variables and $\mathrm{Fe}_{\mathrm{o}}$ also are grouped next to Profile 1, indicating the age of the soil. The data observed for the main component analysis to the surface horizons of the profiles are consistent with the explanations and earlier characterization.

For subsurface horizons, the behavior of the variable distribution was similar to the surface horizons. The observation was contrary to the OM, it is grouped next to the profiles 2 (LAe) and 3 (LVe), in the group 1. These results indicate that in subsurface OM content can increase to soil under pasture, possibly by the amount of roots than grasses can issue in greater depth.

Santos et al. (2015) explain that the multivariate analysis technique can indicate the physical and chemical soil properties that determine more accurately the horizon B diagnosis, identifying more groups that are homogeneous. The authors studied the profile s grouping of "Cambissolos" in Lages, SC. Gomes et al. (2004b) They cite as an alternative for understanding the differences and similarities of pedological environments the main component analysis.

Kummer et al. (2010) studying the main component analysis in soils under different materials of the state of Paraná origin, observed that in soils with higher anthropogenic interference effect of the source material is irrelevant to the grouping of variables. For the soils, as they were under the same source material, it can be said that the group was given according to the pedogenetic processes and anthropogenic area changes.

\section{Conclusion}

The studied profiles were classified as "Cambissolo Háplico Tb eutrófico latossólico", "Latossolo Amarelo eutrófico típico" and "Latossolo Vermelho eutrófico chernossólico", under native forest, degraded pasture and rotated pasture respectively.

The "Cambissolo" Showed higher $\mathrm{SiO}_{2}, \mathrm{Ki}$ and amount of mineral 1:1 (Kt) and better physical and chemical quality than the "Latossolo".

The main component analysis allowed the observation of two groups, Group 1 brought together related properties to "Latossolo", and the second was related to "Cambissolo" properties. Thus, the main components analysis helps in the understanding of soil properties and the grouping of soils with similar characteristics, the level of order and handling.

\section{References}

ANJOS, L. H. C.; PEREIRA, M. G.; PEREZ, D. V.; RAMOS, D. P. Caracterização e classificação de Plintossolos no Município de Pinheiro - MA. Revista Brasileira de Ciência do Solo, Viçosa, MG, v. 31, n. 5, p. 1035-1044, 2007.

ARAÚJO, J. L; ANJOS, L. H. C.; PEREIRA, M. G. Atributos do solo e distinção de pedoambientes para a agricultura na terra indígena Mbya em Ubatuba. Revista Brasileira de Ciência do Solo, Viçosa, MG, v. 33, n. 6, p. 1766-1776, 2009.

BROSSARD, M.; BARCELlOS, A. O. Conversão do Cerrado em pastagens cultivadas e funcionamento de Latossolos. Cadernos de Ciência e Tecnologia, Brasília, v. 22 , n. 1, p. 153-168, 2005.

CAMARGO, L. A.; MARQUES JUNIOR, J.; PEREIRA, G. T.; HORVAT, R. A. Variabilidade espacial de atributos mineralógicos de um Latossolo sob diferentes formas do relevo. I - Mineralogia da fração argila. Revista Brasileira de Ciência do Solo, Viçosa, MG, v. 32, n. 6, p. 2269-2277, 2008.

CAMARGO, O. A.; MONIZ, A. C.; JORGE, J. A.; VALADARES, L. M. A. S. Métodos de análise química, mineralógica e física dos solos do Instituto Agronômico de Campinas. Campinas: Instituto Agronômico, 1986. 96 p. (Boletim técnico, 106). 
CURI, N.; FRANZMEIER, D. P. Toposequence of oxisols from the central plateau of Brazil. Soil Science Society of American Journal, Madison, v. 48, n. 2, p. 341346, 1984.

DICK, D. P. Caracterização de óxidos de ferro e adsorção de fósforo na fração argila de horizontes B Latossólicos. 1986. Dissertação (Mestrado em Solos) - Universidade Federal do Rio Grande do Sul, Porto Alegre.

EMPRESA BRASILEIRA DE PESQUISA AGROPECUÁRIA - EMBRAPA. Manual de métodos de análise de solo. 2. ed. Rio de Janeiro: SNLCS, 2011. $225 \mathrm{p}$.

Sistema brasileiro de classificação de solos. 3 . ed. Brasília: EMBRAPA, 2013. 353 p.

FERNANDES, K. L.; RIBON, A. A.; HERMÓGENES, V. T. L.; CUSTÓDIO, G. D.; BARROS, L. R. Atributos físicos de solo sob cerrado em diferentes sistemas de uso e manejo de pastagens e mata nativa. Cultivando o Saber, Cascavel, v. 7, n. 1, p. 14-27, 2014.

FERREIRA, R. F.A. L.; SOUZA, R. V. C. C.;ANDRADE, F. M.; RIBEIRO, M. R.; CORRÊA, M. M.; LIMA, J. F. W. F. Caracterização física e química de Cambissolos Háplicos da região do maciço de Triunfo no estado de Pernambuco. In: JORNADA DE ENSINO, PESQUISA E EXTENSÃO, 9., 2009, Recife: Anais... Recife: UFRPE, 2009. Disponível em: <http://www.eventosufrpe.com.br/ jepex2009/cd/trabalhos.htm>. Acesso em: 15 jul. 2014.

GHIDIN, A. A.; MELO, V. F.; LIMA, V. C.; LIMA, J. M. J. C. Topossequências de Latossolos originados de rochas basálticas no Paraná: I - mineralogia da fração argila. Revista Brasileira de Ciência do Solo, Viçosa, MG, v. 30, n. 2, p. 293-306, 2006.

GOMES, J. B. V.; CURI, N.; MOTTA, P. E. F.; KER, J. C.; MARQUES, J. J. G. S. M.; SCHULZE, D. G. Análise de componentes principais de atributos físicos, químicos e mineralógicos de solos do bioma Cerrado. Revista Brasileira de Ciência do Solo, Viçosa, MG, v. 28, n. 1, p. 137-153, 2004b.

GOMES, J. B. V.; CURI, N.; SCHULZE, D. G.; MARQUES, A. A. G. S. M.; KER, J. C.; MOTTA, P. E. F. Mineralogia, morfologia e análise microscópica de solos do bioma cerrado. Revista Brasileira de Ciência do Solo, Viçosa, MG, v. 28, n. 4, p. 679-694, 2004a.

INDA, A. V.; TOMASI, C. A.; OLIVEIRA, J. S.; FINK, J. R. Óxidos de ferro e área superficial de Latossolo subtropical sob campo e floresta nativa. Ciência Rural, Santa Maria, v. 44, n. 2, p. 289-292, 2013.

INDA JUNIOR, A. V.; KAMPF, N. Avaliação de procedimentos de extração dos óxidos de ferro pedogênicos com ditionito-citrato-bicarbonato. Revista Brasileira de Ciência do Solo, Viçosa, MG, v. 27, n. 6, p. 1139-1147, 2003.

Variabilidade de goethita e hematita via dissolução redutiva em solos de região tropical e subtropical. Revista Brasileira de Ciência do Solo, Viçosa, MG, v. 29, n. 6, p. 851-866, 2005.

INSTITUTO BRASILEIRO DE GEOGRAFIA E ESTATÍSTICA - IBGE. Mapas temáticos. Brasília: IBGE, 2004. Disponível em: <www.ibge.gov.br>. Acesso em: 17 fev. 2014.

JACKSON, M. L. Soil chemical analysis. $2^{\text {th }}$ ed. Madison: Soil Science Society of America, 1985. 930 p.

KÄMPF, N.; SCHWERTMANN, U. Avaliação da estimativa de substituição de Fe por Al em hematitas de solos. Revista Brasileira de Ciência do Solo, Viçosa, MG, v. 22, n. 2, p. 209-213, 1998.

Goethite and hematite in a climosequênce in Southern Brazil and their application in classification of kaolinite Soils. Geoderma, Amsterdam, v. 29, n. 1, p. 2739, 1982.

KLUG, H. P.; ALEXANDER, L. E. X-ray diffraction procedures for polycrystalline and amorphous materials. New York: J. Wiley Sons, 1974. 966 p.

KUMMER, L.; MELO, V. F.; BARROS, Y. J.; AZEVEDO, J. C. R. Uso da análise de componentes principais para agrupamento de amostras de solos com base na granulometria e em características químicas e mineralógicas. Scientia Agrícola, Piracicaba, v. 11, n. 6, p. 469-480, 2010.

LIMA NETO, J. A.; RIBEIRO, M. R.; CORRÊA, M. M.; SOUZA JÚNIOR, V. S.; ARAÚJO FILHO, J. C.; LIMA, J. F. W. F. Atributos químicos, mineralógicos e micro morfológicos de horizontes coesos de Latossolos e Argissolos dos tabuleiros costeiros do estado de alagoas. Revista Brasileira de Ciência do Solo, Viçosa, MG, v. 34, n. 2, p. 473-486, 2010.

MEHRA, O. P.; JACKSON, M. L. Iron oxide removed from soils and clays by dithionitecitrate system buffered with sodium bicarbonate. Clays and Clay Minerals, Atlanta, v. 7, n. 1, p. 1317-327, 1960.

RODRIGUES NETTO, A. Influência da mineralogia da fração argila sobre propriedades físico-químicas de solos brasileiros. Viçosa, MG, 1996. Dissertação (Mestrado em Agronomia) - Departamento de Ciências do Solo, Universidade Federal de Viçosa, Viçosa, MG.

NORRISH, K.; TAYLOR, R. M. The isomorphous replacement of iron by aluminum in soil goethite. Journal of Soil Science, Oxford, v. 12, n. 2, p. 294-306, 1961. 
OliveIRA, J. B. de. Pedologia aplicada. Piracicaba: FEALQ, 2008. $592 \mathrm{p}$.

PEREIRA, T. T. C.; KER, J. C.; SHAEFER, E. G. R.; BARROS, N. F.; NEVES, J. C. L.; ALMEIDA, C. C. Gênese de Latossolos e Cambissolos desenvolvidos de rochas pelíticas do grupo Bambuí - Minas Gerais. Revista Brasileira de Ciência do Solo, Viçosa, MG, v. 34, n. 4, p. 1283-1295, 2010.

RAIJ, B. V.; CANTARELlA, H.; QUAGGIO, J. A.; FURLANI, A. M. C. Recomendações de adubação e calagem para o estado de São Paulo. 2. ed. Campinas: Instituto Agronômico/Fundação IAC, 1997. 285 p. (Boletim técnico, 100).

REATTO, A.; CORREA, J. R.; SPERA, S. T.; MARTINS, E. S. Solos do bioma Cerrado: Aspectos pedológicos. In: SANO, S. M.; ALMEIDA, S. P. de; RIBEIRO, J. F. Cerrado, ecologia e flora. Brasília: Embrapa Informações Tecnológicas, 2008. v. 2, p. 107-150.

RESENDE, T. M.; MORAES, A. R.; FRANCO, F. O.; ARRUDA, E. M.; ARAÚJO, J. R.; SANTOS, D. S.; BORGES, E.; RIBEIRO, B. T. Avaliação física do solo em áreas sob diferentes usos com adição de dejetos de animais no bioma Cerrado. Bioscience Journal, Uberlândia, v. 28, n. 1, p. 179-184, 2012.

RIBEIRO, J. F.; WALTER, B. M. T. As principais fitofisionomias do bioma Cerrado. In: SANO, S. M.; ALMEIDA, S. P. de; RIBEIRO, J. F. Cerrado, ecologia e flora. Brasília: Embrapa Informações Tecnológicas, 2008. v. 2, p. 151-212.

SANTOS, A. C.; PEREIRA, M. G.; ANJOS, L. H. C.; BERNINI, T. A.; COOPER, M.; NUMMER, A. R.; FRANCELINO, M. R. Gênese e classificação de solos numa Topossequências de morros do médio vale do Paraíba do Sul, RJ. Revista Brasileira de Ciência do Solo, Viçosa, MG, v. 34, n. 4, p. 1297-1314, 2010.

SANTOS, P. G.; BERTOL, I.; MIQUELLUTI, D. J.; ALMEIDA, J. A.; MAFRA, A. L. Agrupamento de profiles de Cambissolos húmicos com base em atributos físicos e químicos utilizando a estatística multivariada. Revista Brasileira de Ciência do Solo, Viçosa, MG, v. 39, n. 2, p. 350-360, 2015.
SANTOS, R. D. dos; LEMOS, R. C. de; SANTOS, H. G. dos; KER, J. C.; ANJOS, L. H. C. dos; SHIMIZU, S. H. Manual de descrição e coleta de solo no campo. 6. ed. Viçosa, MG: Sociedade Brasileira de Ciência do Solo, 2013. 100p.

SILVA, F. W. R.; LIMA, H. N.; TEIXEIRA, W. G.; MOTTA, M. B.; SANTANA, R. M. Caracterização química e mineralogia de solos antrópicos (terras pretas de índio) na Amazônia central. Revista Brasileira de Ciência do Solo, Viçosa, MG, v. 35, n. 3, p. 673-681, 2011.

SILVA NETO, L. F.; INDA, A. V.; BAYER, C.; DICK, D. P.; TONIN, A. T. Óxidos de ferro em Latossolos tropicais e subtropicais brasileiros em plantio direto. Revista Brasileira de Ciência do Solo, Viçosa, MG, v. 32, n. 5, p. 1873-1881, 2008.

SOUZA, D. M. G.; MIRANDA, L. N.; OLIVEIRA, S. A. Acidez do solo e sua correção. In: NOVAIS, R. F.; ALVAREZ, V. H.; BARROS, N. F.; FONTES, R. L. F.; CANTATUTTI, R. B.; NEVES, J. C. L. Fertilidade do solo. Viçosa, MG: SBCS, 2007. p. 205-374.

SOUZA, R. V. C. C.; RIBEIRO, M. R.; SOUZA JUNIOR, V. S. S.; CORRÊA, M. M.; ALMEIDA, M. C.; CAMPOS, M. C. C.; RIBIERO FILHO, M. R.; SCHULZE, M. B. B. Caracterização de solos em uma topoclimossequência no Maciço de Triunfo - Sertão de Pernambuco. Revista Brasileira de Ciência do Solo, Viçosa, MG, v. 34, n. 4, p. 1259-1270, 2010.

STOLF, R. Teoria e teste experimental de fórmulas de transformação dos dados de penetrômetro de impacto em resistência do solo. Revista Brasileira de Ciência do Solo, Viçosa, MG, v. 15, n. 2, p. 229-35, 1991.

VENDRAME, P. R. S.; EBERHARDT, D. N.; BRITO, O. R.; MARCHÃO, R. L.; QUANTIN, C.; BECQUER, T. Formas de ferro e alumínio e suas relações com textura, mineralogia e carbono orgânico em Latossolos do Cerrado. Semina: Ciências Agrárias, Londrina, v. 32, n. 1, p. 1657-1666, 2011.

ZANELLI, R.; EGLI, M.; MIRABELLA, A.; GIACCAI, D.; ABDELMOULA, M. Vegetation effects on pedogenetic forms of $\mathrm{Fe}, \mathrm{Al}$ and $\mathrm{Si}$ and on clay minerals in soils in Southern Switzerland and Northern Italy. Geoderma, Amsterdam, v. 141, n. 2, p. 119-129, 2007. 
